\title{
NEO-MARXISME IN DIE TEOLOGIE - WYSGERIG BESKOU
}

\author{
P. Jansen van Veuren
}

Departement Wysbegeerte RAU

\section{Die ontmoeting tussen Neo-Marxisme en Christelike Teologie: van anatema tot dialoog}

Die breë veld van die ontmoeting tussen Neo-Marxisme en Christelike Teologie laat 'n groot aantal variante van die ontmoeting sien. Die variante van ontmoeting deurloop 'n skaal vanaf felle konfrontasie tot 'n toenadering waarin dit lyk of Christelike Teologie geheel en al opgehef word in Marxistiese teorie ${ }^{1}$. Waar daar in die ontmoeting sprake is van die Teologie wat aan die Neo-Marxisme die hand reik, is daar ook groot verskille in die wyse waarop toenadering gesoek word.

Om die veld van komplekse verhoudinge in die ontmoeting meer oorsigtelik te maak, is dit nuttig om te onderskei tussen twee duidelike gestaltes wat die ontmoeting reeds aangeneem het. Die een kan getipeer word as ,die ontmoeting in dialoog”, soos dit gevoer is tussen teoloë en Marxiste op verskillende konferensies. Die ander gestalte van die ontmoeting kan getipeer word as "die kritiese resepsie van Neo-Marxistiese impulse in die Christelike Teologie". Hierdie bewerking van Marxistiese impulse in die Teologie loop uit op 'n teologiese stroming wat losweg ,politieke Teologie” genoem kan word. Tot hierdie rigting in die Teologie word o.a. J. B. Metz, J. Moltmann, D. Sölle en R. Shaull gereken. Tipiese eienskappe van politieke Teologie is ' $n$ herwaardering van die eskatologiese inhoud van die Bybel in 'n ,politieke” konteks. Die term ,politiek” moet hier breed opgeneem word: dit dui op die geheel van die georganiseerde maatskaplike betrekkinge waarin mense leef en waarin hulle vryheid en verantwoordelikheid konkreet gestalte moet kry. Politieke Teologie is verder - ten minste volgens die bedoeling van sy beoefenaars - nie 'n ,suiwer teorie" nie, maar van meet af aan 'n aanwysing tot handeling. In hierdie praxis-betrekking van die teorie distansieer die "politieke Teologie" homself die duidelikste van die „tradisionele Teologie".

Vór 1960 was die verhouding tussen Marxisme en Christelike Teologie van so 'n aard dat die ontmoeting tussen die twee uitsluitlik op vyandige konfrontasie neergekom het. Wat het verandering in hierdie situasie teweeg gebring in die jare sestig? Daar kan ten minste vier belangrike voorwaardes vir die verandering tussen neoMarxisme en Christelike Teologie aangewys word.

Die vernuwingsbeweging in die Oos-Europese Marxisme ná die twingtigste Partykongres van die Kommunistiese Party in 1956 het 'n proses van „destalinisasie" en „versagting" van die Marxistiese denke ingelui. Die belangrikste figure wat hierdie vernuwing gestalte gegee het, is die Poolse filosowe Adam Schaff en Leszek Kolakowski, en die Tjegge Milan Machovec en Viteslav Gardavsky. Die filosofiese vernuwing wat hierdie mense bewerkstellig het, bestaan negatief in die afwysing van die kommunistiese burokrasie 
en van die Marxisme as onveranderbare dogma. Positief bestaan die vernuwing in 'n her-ontdekking van die waarde van die mens en die individue met sy etiese probleme ${ }^{2}$. Kolakowski, Machovec en Gardavsky het hulle self met 'n onderwerp ingelaat wat in die kommunistiese ideologie taboe was, nl. godsdiens en Christendom, en het meer daarin ontdek as blote „opium vir die volk" s.

Neo-Marxisme in Wes-Europa het byna oornag ná 1960 die filosofie van die dag geword met die publikasie van belangrike werke van Ernst Bloch en die „Frankfurter Schule” in Duitsland en van Roger Garaudy in Frankryk. Laasgenoemde se brosjure oor dialoog tussen Marxisme en Christendom was 'n uitdaging tot antwoord van die kant van die Christelike Teologie 4.

Ná 1960 het die politieke en sosiaal-ekonomiese situasie in Europa ingrypend verander: die tydperk van die koue oorlog was iets van die verlede en is vervang met pogings tot „detente" en ko-eksistensie tussen Oos en Wes. Die veranderde politieke situasie het invloed uitgeoefen op die wedersydse evaluasie van Marxiste en Christene: dit het duidelik geword dat ná die Tweede Wêreldoorlog probleme van mondiale omvang ontstaan het en dat hulle slegs deur oorleg tussen Oos en Wes die hoof gebied kan word. In hierdie verband kan die wapenwedloop en die moontlikheid van armageddon in 'n derde wêreldoorlog genoem word.

Binne die Christelike Teologie is reeds sedert die jare vyftig in die diskussie rondom die probleem van sekularisasie ${ }^{\circ}$ temas in die Teologie opgeneem wat op die vlak van die sosiaal-kulturele verantwoordelikheid en bestemming van die mens lê. Dit is juis op hierdie vlak dat daar 'n "gemeenskap van probleme" by die Christelike Teologie en die Neo-Marxistiese Filosofie kon ontstaan.

Die ,ontmoeting in dialoog" tussen Neo-Marxiste en teoloë wat op grond van bogenoemde voorwaardes tot stand gekom het, laat heel spesifieke verhoudings tussen die diskussiegenote uitkristalliseer. Volgens die Neo-Marxiste en teoloë wat aan die internasionale konferensies te Salzburg (1965) en Marienbad (1967) deelgeneem het, is die doelstelling van die dialoog nie die kerstening van die Neo-Marxisme nie, en ook nie die verandering van die Christelike Teologie in 'n variant van Neo-Marxistiese teorie nie. ,Die ,ontmoeting in dialoog" tussen Neo-Marxiste en teoloë het die tendens om die onversoenbare verskilpunte tussen die diskussiegenote sterk na vore te bring, juis omdat daar op 'n aantal probleemgebiede ooreenstemming bereik kan word ${ }^{\circ}$. Algemeen gestel is die resultaat van die dialoog die bevinding dat daar 'n gemeenskap van probleme en vrae bestaan tussen Neo-Marxiste en Christelike teoloë, maar nie 'n gemeenskap van antwoorde nie (Moltmann). Dié basis van ooreenstemming is egter baie smal weens groot prinsipiële verskille tussen die diskussiegenote. Buite die konferensie-dialoog om lé die verhoudings besonder ingewikkeld en is daar verskillende grade van tocnadering tot die Marxisme in die Christelike Teologie en van toenadering tot dic Christelike tradisie by 'n anntal van die Marxiste ?. ..Toenadering" in laasgenoemde verband wil natuurlik nie se dat Marxiste hulle humanistiese en ateïstiese toewyding afsweer nie: dit gaan vir hulle om 'n verwerking van die Christelike oorlewering 
in verband met Jesus in hulle Marxisme. Die Jesus-beeld van die Neo-Marxistiese "Christologieë” staan in die konteks van 'n (humanistiese) herwaardering van die waarde van die mens en sy ,eksistensiële" probleme in verband met die ,sin van die lewe". Hierdie neo-Marxistiese waardering van Jesus blyk meer stof te bied vir 'n gesprek tussen Marxiste en teoloë as die vulgêr-Marxistiese waardering van Jesus as 'n kommunistiese sosiale hervormer.

Om reg te laat geskied aan die nuanses wat optree by toenadering in die Christelike Teologie aan die Neo-Marxisme, is dit wenslik om 'n enkele geval van toenadering vanaf die kant van die Teologie in detail te beskou. Die verhouding tussen Moltmann se teologie van die hoop en Ernst Bloch se variant van Neo-Marxisme toon interessante nuanseringe en leen sig dus tot behandeling as illustratiewe geval. Om sig te verkry op Moltmann se verhouding tot Bloch word vervolgens ingegaan op die hooftemas van Moltmann se teologie, en word Bloch se filosofie vergelykenderwys betrek by Moltmann se beskouinge.

\section{Geskiedenis en eskatologie}

Volgens ' $n$ slordige formulering van Moltmann het Bloch se „teoretiese messianisme" gehelp om die vergete Christelike eskatologie weer tot 'n sinvolle dimensie van die Teologie te maak ${ }^{8}$. Hierdie uitspraak is bevreemdend wanneer herinner word dat die eskatologie by Schweitzer, Barth en Bultmann nie juis 'n vergete hoofstuk in die Teologie is nie. Moltmann se uitspraak word meer verstaanbaar wanneer dit teen die agtergrond van Bultmann se eksistensialistiese teologie gesien word. By Bultmann kom die eskatologie wel aan die orde, maar dan in 'n eksistensiële konteks. Moltmann se belangrikste beswaar teen Bultmann is dat laasgenoemde die vraag na die sin van die geskiedenis in sy geheel tersyde stel as 'n sinlose vraag'. By Bultmann kom die vraag na die sin van die geskiedenis slegs binne die konteks van die individuele eksistensie aan die orde: die geskiedenis as besondere eksistensiële geskiedenis sou sy einde en voleindiging vind in die konkrete eie historisiteit van die persoon wat in die geloof vir Christus beslis. Dit is nuttig om as toeligting hier 'n langerige sitaat te gee uit 'n boek van Bultmann: "It is the paradox of the Christian message that the eschatological event, according to Paul and John, is not to be understood as a dramatic cosmic catastrophe but as happening within history, beginning with the appearance of Jesus Christ and in continuity with this occurring again and again in history, but not as the kind of historic development which can be confirmed by any historian. It becomes an event repeatedly in preaching and in faith.... the meaning of history lies always in the present and when the present is conceived as the eschatological present by Christian faith the meaning of history is realized .... always in your present lies the meaning of history and you cannot see it as a spectator, but only in your responsible decisions. In every moment slumbers the possibility of being the eschatological moment. You must awaken it" ${ }^{10}$. 
Uit hierdie sitaat blyk dat Moltmann se verwysing na 'n „vergete eskatologie" korrek is in dié sin alleen dat die reëel-historiese en universeel-historiese dimensies van die Christelike hoop en eskatologie in vergetelheid geraak het by Bultmann en sy navolgers.

Die vraag moet nou gestel word waarom juis Bloch se filosofie vir Moltmann 'n middel is tot 'n herwinning van die universeelhistoriese karakter van die Christelike eskatologie. 'n Beklemtoning van die universeel-historiese karakter van die Christelike eskatologie sou ook in aansluiting by (byvoorbeeld) Oscar Cullmann ${ }^{11}$ se beskouing van heilsgeskiedenis bereik kan word. Aansluitend by die voorgaande kan gevra word of Moltmann ook inhoudelik aanknoop by Bloch se "teoretiese messianisme".

Wanneer Moltmann belangrike impulse tot teologiese vernuwing vind in Bloch se "teoretiese messianisme”, betrek hy eksplisiet die eskatologiese aksente in Bloch se filosofie by die vernuwing. Die term „messianisme" is in die konteks van Bloch se filosofie 'n komplekse begrip. Op Bloch se filosofie self aangewend, slaan dit op die karakteristieke eskatologiese motiewe in Bloch se denke. By Bloch vind daar 'n uitbreiding van die vervreemdingsbegrip bó die ekonomies-sosiale inhoud van dit by Marx het, plaas. By Bloch is die dood en die verganklikheid van die natuur oor die algmeen ook in die vervreemdingsbegrip vervat ${ }^{12}$. Met hierdie verruimde vervreemdingsbegrip korreleer ' $n$ vervullingsbegrip by Bloch wat ver bo die vervulling van die menslike bestemming in 'n klasselose maatskappy uitgaan: vervulling sluit finaliter ook dood en verganklikheid uit. Deur hierdie verstellinge aan Marx se begrippeapparaat verkry Bloch se variant van Neo-Marxisme 'n kenmerkende eskatologiese aksent. Die term „messianisme” speel verder 'n sleutelrol in Bloch se godsdiensfilosofie. Hier slaan dit op die utopie in die godsdienste - dit wil sê op die antisipasies van 'n menslike bestaan sonder enige vervreemding wat volgens Bloch in alle godsdienste voorkom ${ }^{13}$. Dit is kenmerkend van die program van Bloch se filosofie dat hy die Marxisme wil "verdiep" deur opname van elemente uit die godsdienste. Hierin verskil Bloch van Feuerbach en veral van Marx Die elemente van die godsdienste wat oorbly nadat Bloch hulle aan 'n ateīstiese godsdienskritiek onderwerp het, is die sogenaamde utopiese inhoude van die godsdienste; dit is dié inhoude wat 'n hoogste dcel artikuleer. Volgens Bloch kan die Marxisme op die duur nie klaarkom sonder eskatologiese doelstellings nie. Bloch se Marxisme as „konkrete utopie" bestaan uit 'n integrasie van eskatologiese doelstellings en kort-termyn doelstellings. In hierdie integrasie het die eskatologiese doelstellings die funksie om mense onvoorwaardelik tot rewolusionêre aktiwiteit te omtiveer ${ }^{14}$. Eskatologiese doelstellings kan hierdie motiverende funksie hê omdat in hulle 'n reëel-moontlike vervulling geantisipeer word. Eskatologiese hoop-beelde is volgens Bloch dus nie slegs subjektiewe wensbeelde nie, maar het 'n grond in die werklikheid as objektiewe moontlikheid of "materie" soos Bloch dit ook noem. Die tendense en latente inhoude van die werklikheid waarborg by Bloch dat ook eskatologiese doelstellings moontlik in vervulling kan gaan. 
Daar kan nog kortliks op twee belangrike bepalings van die eskatologiese doel van die geskiedenis by Bloch gewys word. Die doel kán slegs werklik word en is nie reeds reëel nie. Die ongerealiseerde eskatologiese doel is by Bloch ' $n$ korrelaat van die motiverende krag van eskatologiese doelstellings: 'n einddoel wat reeds bestaan, motiveer nie tot handeling wat die realisering daarvan moet bemiddel nie. Tweedens is die eskatologiese doel as „novum" bepaal. Dit het hierdie kwaliteit omdat dit geantisipeer word as 'n bestaan van nie-vervreemding. Alhoewel die eskatologiese doel bo alle vervreemding uitgaan, val dit volgens Bloch nie buite die moontlikhede van die materie nie en moet dit opgevat word as die resultaat van die geskiedenisproses. Die novumkarakter van die eindresultaat van die wêreldproses kan gesien word as die ontologiese korrelaat van Bloch se ateïsme-tese: utopie as egte novum impleseer dat die geskiedenisproses nie in 'n reeds bestaande "hoogste doel" uitmond nie, en ook nie volgens 'n vasstaande goddelike plan verloop nie.

Die voorgaande verduideliking van die inhoud van Bloch se "teoretiese messianisme" is voldoende voorbereiding om die vraag wat hierbo gestel is, te beantwoord. Wat die eintlike belang van Bloch se "teoretiese messianisme" vir Moltmann is, word duidelik uit sy uitspraak dat ,die sending van die gemeente slegs verstaanbaar is indien die opgestane Christus self nog 'n toekoms het" ${ }^{10}$. „Sending" is by Moltmann een van die sentrale momente van die praxis van die Christelike hoop. By Moltmann vind daar ' $n$ verbinding plaas tussen praxis en die eskatologiese inhoude van die Christelike hoop, analoog aan Bloch se verbinding van rewolusionêre praxis en die eskatologiese hoop-inhoude van die konkrete utopie. Daar is ' $n$ duidelike ooreenkoms tussen Moltmann en Bloch op die punt van die onafgeslotenheid en ongerealiseerdheid van die eskatologiese inhoude: hierdie status van die eskatologiese inhoude is by albei 'n voorwaarde vir 'n sinvolle verbinding tussen die eskatologiese en menslike praxis. Dit gaan dus by Moltmann nie om 'n blote herwinning van die universeel-historiese betekenis van die Christelike eskatologie nie, maar om die herwinning daarvan op só 'n wyse dat die eskatologie relevant word vir menslike praxis. In hierdie verband is Bloch se filosofie dan 'n onvervangbare voorbeeld van Moltmann.

Nadat die fundamentele ooreenstemming tussen Bloch en Moltmann na vore gebring is, moet ook gewys word op die ewe belangrike punte van verskil tussen hulle. Dat dit in die verskilpunte nie om kleinighede gaan nie, blyk uit Moltmann se oordeel dat ,die Christelike hoop homself slegs in 'n verwronge gestalte in Bloch se fenomenologie van die hoop kan herken ${ }^{16}$.

Een van die belangrikste aansprake van Moltmann se teologie van die hoop is dat dit in 'n herbesinning op die oorspronklike Bybelse getuienis in verband met die opstanding van Jesus die oorspronklike eskatologiese betekenis van hierdie gebeurtenis herwin het. Die oorspronklike betekenis van die opstandingsgebeure is geleë in die „Zukunft des Auferstandenen" ${ }^{17}$. Wanneer daar oor die toekoms in die konteks van die eskatologie gepraat word, gaan dit gewoonlik oor die toekoms wat Christus vir die gelowiges verwerf 
het, en word daar aangeneem dat Christus self oor kruis, opstanding en hemelvaart heen geen verdere geskiedenis sal deurloop nie. Wie en hoe Christus ná sy hemelvaart is, word gewoonlik as vastaande en buite-histories opgevat. Daar is dan nog slegs sprake van toekomstige kennis oor Christus: wie en hoe $\mathrm{Hy}$ reeds is, sal in ' $n$ eskatologiese toekoms openbaar gemaak word aan mense. Moltmann se gedagte van die „,Zukunft des Auferstandenen” gaan lynreg téén hierdie tradisionele opvatting oor die eskatologiese Christus in. Volgens Moltmann praat die Christelike eskatologie van „Jesus Christus und seiner Zukunft" ${ }^{18}$. Moltmann meen dat hy die inhoud van die Nuwe Testamentiese verkondiging oor die opstanding van Christus adekwaat weergee as hy sê dat daar iets is in die werklikheid van Christus se opstanding wat nog nie verwesenlik is nie en nog latent is: „Aangesien dit 'n gebeure is wat as ' $t$ ware onafgeslote is en wat in toesegging van universele heil nog voorlopig en onvoltooid is, is openbaring van God in die opwekking van Christus tot in die struktuur van die gebeure belofte. Dit dui op 'n nuwe werklikheid wat nog nie is nie...." ${ }^{10}$. Wat in hierdie sitaat oor Christus uitgespreek word, geld volgens Moltmann ook van God op grond van die ,aanwesigheid" van God in die gekruisigde en verhoogde Christus: „In die opwekking van die gekruisigde kan in die nag van die verlatene 'n voorskyn gesien word van die ryk waarin God God is en tot sy identiteit in die skepping kom, waarin die mens tot vryheid kom en vrede en geregtigheid op aarde heers" 20. Vanuit die gedagte van die "aanwesigheid" van God in Christus, word Moltmann se bevreemdende uitsprake oor die "toekomstige godheid van God" en oor die „optsanding van God" verstaanbaar ${ }^{21}$.

Die „oorspronklike” Bybelse eskatologie, waarin nie slegs die mens en die wêreld nie, maar ook Christus en God 'n toekoms het, onderskei volgens Moltmann die Bybelse geloof in God se beloftes van alle godsdienste waarin die goddelike as "voorhande" opgevat word en ook van die filosofiese teologie wat die goddelike as 'n onveranderlike hoogste syn opvat. In die Bybelse eskatologie is daar ook geen aanknopingspunt vir 'n ,presentiese" eskatologie soos dit eksistensialisties deur Bultmann uitgewerk word nie.

In sy beskrywings van die eskatologiese betekenis van die opstandingsgebeure neem Moltmann die terme „tendens" en „latensie" uit Bloch se filosofie oor. Die oorname van terminologie dui in hierdie geval nie op inhoudelike oornames uit Bloch se filosofie in die teologie van die hoop nie. Die terme "tendens" en "latensie" is fundamentele kategorieë van Bloch se spekulatiewe materiebeskouing. In die gebruik wat Moltmann daarvan maak, kom hulle in 'n heel ander konteks te staan: die terme "tendens" en "latensie" word deur Moltmann nie as ontologiese kategorieë gebruik nie, maar op Christus betrek: „tendens" slaan hier op die toekomsrigting wat gegee is met die opwekking van Jesus uit die dood, en "latensie" slaan op die heerskappy van Christus wat nog in die nederigheidsvorm van die kruis verborge is. Daarenteen slaan "latensie" by Bloch op die "oopheid" van die doel van die geskiedenis: eskatologiese vervulling of mislukking is nog in die weeg- 
skaal. By Moltmann is die eskatologiese heerskappy van Christus nie in die weegskaal nie, maar vir die geloof en hoop gewis omdat „God die mag het om dooies lewendig te maak en wat nie is nie, in bestaan te roep" ${ }^{23}$.

3. Van eksistensiële sorge tot sorg vir die wêreld: die praxis van die hoop

Moltmann se belangrikste verwyt aan die eksistensialistiese teologie van Bultmann is dat by laasgenoemde geloof en hoop bloot innerlik bly. By Bultmann is daar wroeging, stryd, opoffering en vernuwing in ,beslissings" en „ontmoetings”. Maar dit bly alles innerlik en daarbuite in die sosiale en politieke lewe van mense word niks verander nie. Bultmann se teologie lei dus tot quietisme op die gebied van sosiale en politieke praxis ${ }^{24}$. Moltmann wil Bulmann se eksistensialisme uit die weg ruim deur te argumenteer vir die wêreldbetrokkenheid van die Christelike eskatologiese hoop. Ook hier gaan Moltmann in sy argumentasie uit van wat hy beskou as die kern van die Christelike eskatologie, naamlik „Jesus Christus en sy toekoms". Jesus se toekoms is volgens Moltmann radikaal op die mense en die wêreld betrokke: „Die Paasgetuienisse neem die Opgestane nie in die glans van die hemelse bo-aardse ewigheid waar nie, maar in die voorskyn en in die aanbreek van sy eskatologiese toekoms tot die wêreld" ${ }^{25}$. Die crux van Moltmann se argumentasie is die gedagte dat Christus se toekoms 'n ,Zukunft zur Welt" is. Christelike praxis moet dan vór alles in diens van Christus se toekoms staan. As dit wel gebeur, is Christelike praxis nie bloot „innerlik" of wêreldvreemd nie, maar juis gerig op die wêreld. Die wêreldgerigte praxis van die eskatologiese hoop is volgens Moltmann eerstens "sending" in die wêreld in ${ }^{28}$. Onder „sending” verstaan Moltmann prediking van die Evangelie, gemeentevorming en verder ook in samehang daarmee: „Verwirklichkung eschatologischer Rechtfertigung, Humanisierung des Menschen, Sozialisierung der Menschheit, Frieden der ganzen Schöpfung" ${ }^{27}$.

Hiermee het Moltmann daarin geslaag om die Christelike eskatologiese hoop vanuit sy kern op die wêreld te betrek. Die belangrikste teoretiese moeilikhede van Moltmann se praxis-beskouing sentreer egter juis rondom dié verhouding tussen die eskatologiese hoop en die wêreld. Kritiese vrae aan Moltmann oor sy praxisbeskouing word opgeroep deur die growwe teenstelling waarin die werklikheid van God se beloftes (inklusief Jesus se opstanding) en die bestaande werklikheid met mekaar te staan kom. Die inhoud van die belofte is by Moltmann 'n negasie van die geworde wêreld: „Wat dit ook was wat daar verskyn het en as sy heerlikheid beskou word, dit kan in die wêreld van Christus se kruis, van die sonde en die dood geen ander ooreenstemming vind as in die kategorieë van belofte en teenspraak van die Evangelie nie" ${ }^{28}$. Teenoor die (eskatologiese) heerskappy van Christus wat in die opstandingsgebeure ,aangekondig" en "geopen" is, teenoor die wêreld soos dit "kan wees" en "sal wees", verskyn die voorhande wêreld as „ellendige werklikheid" en as "skyn" ${ }^{2 \theta}$. 
Die vraag kan aan Moltmann gestel word of die belofte - soos hy dit opvat - nie bloot 'n abstrakte negasie, 'n bloot vernietigende negasie van die bestaande werklikheid inhou nie. In hierdie verband word die gevaar van 'n gnostisisme, van 'n vervalle wêreld en 'n heilswerklikheid wat teenoor mekaar staan, akuut by Moltmann, wat juis in ' $n$ ander konteks self 'n gnostiese tweedeling tussen heilsgebeure en wêreldgeskiedenis afwys ${ }^{30}$. Wanneer die belofte ' $n$ bloot vernietigende negasie is van ' $n$ vervalle wêreld, word dit tot 'n blote formule wat die toekomstige verlossing besweer en die voorhande wêreld steeds as demonies reproduseer. In die lig van die belofte blyk eers die ellendigheid van die bestaande wêreld ${ }^{31}$. In hierdie verband kan daar ook gevra word of die eskatologiese geloof en hoop hom slegs kan beweeg in die gebied tussen die "skyn" van die bestaande wêreld en die "voor-skyn" van die toekomstige wêreld. Is daar dan nie iets soos die presensie van die heil nie - al verkeer dié "resensie" dan ook nog in die spanning tussen ,alreeds" en „nog nie". Moltmann neem hierdie probleem wel op waar hy die volgende sê: „Die Woord van God bied reeds wat dit beloof, naamlik Homself, versoening en gemeenskap met Hom, dog nie op 'n ander wyse nie as dat dit Homself, sy heerlikheid beloof" 32. Hierdie uitspraak grens aan verbale oëverblindery, want al wat dit sê is dat God, versoening en gemeenskap met Hom in belofte present is. Maar dit is juis teenoor dié belofte dat die wêreld in sy vervallenheid verskyn.

In die lig van die voorgaande moet die vraag hoe die hoop dan prakties kan word, met nadruk aan Moltmann gevra word. As onder praxis van die hoop ook sosiale verandering verstaan word, moet rekenskap gegee word van wat gewoonlik die „objektiewe voorwaardes" van sosiale verandering genoem word. Moltmann praat by geleentheid oor „die reële moontlikhede van die wêreldwerklikheid" ss en van ,kanse vir die praxis van Christelike vryheidshoop" ${ }^{34}$, maar dié verwysings staan steeds in 'n skrille kontras met die totale vervallenheid van die voorhande werklikheid wat andersyds sterk deur Moltmann beklemtoon word. Moltmann probeer finaliter tussen die eskatologiese inhoude van die hoop en die voorhande wêreld 'n bemiddeling bewerkstellig - waarsonder die hoop sinloos sou word - deur te verwys na God se „praxis": die vervalle werklikheid bied uit sigself geen uitweg uit sy vervallenheid nie, maar die wêreld soos dit „kan wees" en "sal wees" kan verwag word uit 'n skeppingsdaad van God, 'n "novum ex nihilo" ss. Op hierdie punt kan daar verwys word na 'n belangrike verskil tussen Bloch en Moltmann: in Bloch se filosofie is dit sy spekulatiewe materie-begrip wat 'n bemiddeling tussen ,hierdie wêreld" en die eskatologiese wêreld bewerkstellig: by Moltmann word daar na 'n kreatiewe daad van God verwys. Hiermee is die teoretiese moontlikhede wat hierbo genoem is, bedwing, maar daar kom juis in hierdie verband ' $n$ nuwe probleem op, naamlik: hoe moet die verhouding tussen God se „praxis" en menslike praxis opgevat word? Watter betekenis moet aan menslike praxis toegeken word?

Volgens Moltmann is die Christelike praxis-begrip van die eskatologiese hoop verskillend van die "gewone" praxisbegrip van sosiale 
verandering, want eersgenoemde is geöriënteerd aan 'n bevryding wat méér as die polities-sosiale omvat, dit is geöriënteerd aan 'n totale bevryding van die omvattende ellende van die mens wat leef onder die mag van ", sonde, dood en duiwel" "s6. In die praxis van missionêre verkondiging gaan dit volgens Moltmann om verkondiging van die kruis van Christus as ,uitdrukking" van die werklike menslike ellende en van die opwekking van Christus as die ware protes teen dié ellende. Só gesien kan verkondiging nie verwyt word dat dit ,opium vir die volk" is nie: dit is gerig op bevryding van onvryheid en ellende. Volgens Moltmann word op hierdie wyse die omvattende vryheid wat geleë is in die toekomstige nuwe skepping deur God antisiperend present gestel „as" verkondigde Woord, gemeenskap en reële gehoorsaamheid ${ }^{37}$. Hiermee het Moltmann ' $n$ aanduiding gege van waarin vryheid positief sou moet bestaan; by nadere beskouing blyk egter dat dit by verkondiging, gemeentevorming en lewe in gehoorsaamheid steeds gaan om bevryding en nie om gerealiseerde vryheid nie ${ }^{38}$.

Die primaat wat aan bevryding in Moltmann se vryheidsbeskouing toekom, blyk eksplisiet uit die antwoord on die vraag wat Moltmann self stel na die produk van Christelike praxis in die maatskappy: „Wat rig die gemeente wat aldus in God se geskiedenis opgeneem is binne die maatskappy waarin dit leef, uit?" ${ }^{39}$. In sy antwoord op hierdie vraag ken Moltmann aan die praxis van die "gemeente" in die samelewing 'n negatiewe funksie toe: dit is die opgawe van die gemeente om deur haar bestaan en praktiese getuienis te sorg dat die maatskaplike institusies nie mities of ideologies verselfstandig word nie, want dan word hulle afgesluit van God se eskatologiese toekoms. Moltmann wys dus 'n negatiewe vorm van praxis toe aan die ,gemeente" om die sosiale werklikheid „oop" te hou vir die toekoms van God ${ }^{40}$. Aan menslike praxis kan dus slegs negatiewe doelstellings gestel word: likwidering van voorhande onvryheid en verselfstandigde sosiale verhoudings; die eskatologiese inhoud van die vryheid word van 'n vrye beslissing van God verwag op grond van die opwekking van Jesus uit die dood ${ }^{41}$. Juis deurdat slegs negatiewe doelstellings vir menslike praxis gestel word om die nuwe (gerealiseerde) vryheid inhoudelik onbepaald te laat, vind Moltmann op hierdie punt wrywingloos aansluiting by Bloch en Marx, soos blyk uit die volgende uitsprake: „Ware toekomsbewussyn van die vryheid is lewendig in die kategoriese imperatief, om alle verhoudings omver te werp waarin die mens 'n vernederde, verknegte, verlate en veragte wese is" ${ }^{42}$. En: „Vir die teoloë is dit nie slegs 'n doelstelling om die geskiedenis en die menslike bestaan slegs anders te interpreteer nie, maar dit in die verwagting van Goddelike verandering te verander" ${ }^{43}$. Wat presies die inhoud van hierdie verandering is, word nie deur Moltmann eksplisiet gemaak nie; ook die terme „humanisering” en „,sosialisering" bly by Moltmann formeel. Dat menslike praxis op een of ander manier met God se „praxis" saamhang, is by Moltmann meer 'n postulaat as 'n saak wat deur argumente aanneemlik gemaak word.

Met betrekking tot die primaat wat hy aan bevryding toeken, 
is daar 'n belangrike punt van verskil tussen Moltmann en Marx: by laasgenoemde is die omverwerping van die verknegtende verhoudings van die kapitalistiese maatskappy die vernietigende oordeel wat dié maatskappy oor homself voltrek en waaruit dan op een of ander manier die klasselose maatskappy sou resulteer. By Moltmann is die likwidasie van die verknegtende verhoudings die oordeel van God se toekoms oor 'n gevalle wêreld, en word die eskatologiese vryheid uit die niks van die vernietiging verwag van 'n kreatiewe daad van God. In hierdie verband kan die verwyt wat Moltmann aan Karl Barth rig ${ }^{44}$, in 'n ietwat gewysigde vorm op Moltmann self aangewend word: by Moltmann is die eskatologiese „woord" nie aantasbaar nie, maar dit is ook nie by magte om enigiets wat reeds bestaan, aan te tas nie, behalwe in die totale likwidasie daarvan. Op hierdie punt verkry Moltmann se beskouing - teen sy bedoeling in ${ }^{45}$-'n quietistiese trek met betrekking tot die realisering van positiewe inhoude van vryheid omdat sulke historiese inhoude van meet af aan nietig is teenoor die eskatologiese vryheidsinhoud.

\section{Samevatting en opgawe}

In die plek van 'n nuwe verwoording van sake wat alreeds hierbo aan die orde was, kan tot 'n samevatting gekom word deur 'n verdere kritiese vraag en 'n kritiese opmerking aan Moltmann se adres te rig. Eerstens kan gevra word of Moltmann nie té maklik tot ' $n$ identifisering van 'n eenduidige negatiewe kom nie. By Moltmann is die kwaad as sodanig eenduidig: dit bestaan in die verstarde sosiale verhoudings wat die uitsig op God se eskatologiese toekoms versper. Die geworde wêreld is "skyn" en „vervallenheid" teenoor die eskatologiese toekoms en moet steeds in 'n eksodus verlaat word op die weg na die toekoms toe. Dit is egter 'n vraag of die negatiewe histories in eenduidige bepaaldheid voorkom. In sy kritiek op die eksistensialisme het Moltmann 'n waarheid wat hier ingesien is, misgekyk: die „eksistensiële" dimensie van die geskiedenis wat geleë is in die dubbelsinnigheid van historiese gebeure en historiese gestaltes. In die geskiedenis kom die „suiwer negatiewe" en ook die ,suiwer positiewe" slegs by wyse van antisipasie en nie reëel voor nie. Waar daar iets positiefs( met betrekking tot vryheid en geregtigheid) verwerklik word, dring die kwaad ook in en haal mense skuld op hulleself; in die afskaffing van die negatiewe word meestal ook iets wat positief is, vernietig en staan mense ook skuldig. Die weg van die praxis van bevryding is histories meer gedifferensieerd en gefragmentariseerd as wat Moltmann in sy beskouing laat blyk of selfs kan laat blyk. Daarom vind die probleme van die bewaring van verworwe vryhede (sonder reaksionêre interesse!) en van die stryd tussen tradisie en vernuwing in Moltmann se beskouing geen heenkome nie en bly hulle as onvervulde opgawes staan vir verdere teoretiese besinning.

Die verwyt kan aan Moltmann gerig word dat hy sy eie program nie bevredigend uitvoer nie. In sy konfrontasie met die filosofie van Ernst Bloch stel Moltmann dat die „christliche Theologie sich von 
ihm zur Erneuerung ihrer selbst provoziert fühIt" 46 en dat hy homself nie as ' $n$ Blochiaan sien nie, ",sondern vielmehr zum Eigenen ermutight" ${ }^{47}$. Uit die bespreking (hierbo) van Moltmann se praxisbeskouing het geblyk dat hy egter juis op dié punt, waar dit gaan om die aanduiding van positiewe inhoude van „verandering”, „, sosialisering" en „humanisering”, in gebreke bly om die „eie" tot gelding te bring, die Christelike Teologie tot 'n vernuwing van ,sigself" te voer. Hier is dus volgens Moltmann se eie program 'n onvervulde en ook onontwykbare opgawe waaraan gewerk moet word met die nodige besef van die eise van ons tyd en van die voorlopigheid van mensewerk.

1 Byvoorbeeld die "Tegenspraakgroep" in Nederland; vide hieroor J. Sperna Weiland: Voortgezette Oriëntatie. Baarn, Het Wereldvenster, 1971, p. 123 seq.

2 Vide: A. Schaff: Marxismus und das menschllche Individuum Wien, Europa-Verlag, 1965; M. Machovec: Vom Sinn des menschllchen Lebens. Freiburg 1. .Br., 1971.

3 Vide: L kolakowskl: Geist und Ungeist Christlicher Traditionen. Stuttgart, W. Kohlhammer, 1971; M. Machovec: Marxismus und dialektische Theologie. Zuruch, EVZ Verlag, 1965; V. Gardavsky: Gott ist nlcht ganz tot. Munchen, Chr. Kaiser Verlag, 1968.

4 R. Garaudy: „Vom Bannfluch zum Dialog”, opgeneem met antwoorde daarop deur Katolieke teoloë uit: Garaudy, Metz, Rahner: Der Rialog. Rowolt, 1966.

5 Vide in hierdie verband: Friedrich Gogarten: Verhăngnis und Hoffnung der Neuzeit. Die Säkularisierung als theologisches Problem. Stuttgart, 1953; B. Rietveld: Saecularisatie als probleem der theologische ethiek, Inzonderheid in verband met gedachten van Dietrich Bonhoeffer en Friedrich Gogarten. (Dissertasie V.U. Amsterdam, 1957) 's-Gravenhage, 1957.

6 Vide: Garaudy, Metz, Rahner: op cit.; E. Kellner (red.): Christentum und Marxismus - heute. Wien, Europa Verlag, 1966 (Nederlandse vertaling: Christendom en Marxisme. Utrecht, Ambo, 1967); H -J. Girock (red.): Partner von Morgen?, Das Gespräch zwischen Christentum und marxistlschen Atheismus. Stuttgart-Berlin, Kreuz-Verlag, 1968.

7 Opmerklike toenadering is te vinde by M. Machovec (Vom Sinn des menschlichen Lebens) en by L. Kolakowski (Geist und Ungeist Christlicher Traditionen).

8 J Moltmann: „Die Apokalyptik im Messianismus” (1967) in B. Schmidt: Materiălen zu Ernst Blochs „Prinzip Hoffnung”. Frankfurt-am-Main, Suhrkamp, 1978, p. 491.

9 J. Moltmann: Perspektiven der Theologie. München, Chr. Kaiser Verlog, 1968, pp. 86, 132.

10 R. Bultmann: History and Eschatology. Edinburgh, The University Press, 1957, pp. 151-154.

11 O. Cullmann: Christus und die Zeit. Die urchristliche Zeit- und Geschichtsauffassung Zollikon-Zürich, Evangel. Verlag A.G., 1946.

12 Vide: :Ernst Bloch: Atheismus im Christentum (Gesammtausgabe 14). Frankfurt-am-Main, Suhrkamp Verlag, 1977, p. 350; Das Materialismusproblem (Gesammtausgabe 7), p. 407.

13 Vide: Ernst Bloch: Das Prinzip Hoffnung (Gesamtausgabe 5), p. 1413.

14 Ibidem, p. 235 seq. 
15 J. Moltmann: Theologie der Hoffnung. München, Chr. Kaiser Verlag, 1969, p. 73.

16 J. Moltmann: Perspektiven der Theologie, p. 175.

17 Vide: J Moltmann: Theologie der Hoffnung, p. 13.

18 Idem,

19 J. Moltmann: Perspektiven der Theologie, p. 29.

20 Ibidem, p. 48.

21 Ibidem, p. 28.

22 Vide: J. Moltmann: :Theologie der Hoffnung, p. 177 seq.

23 Ibidem, p. 131.

24 Vide: J. Moltmann: Perspektiven der Theologie, pp. 20, 107 seq., 134

25 J, Moltmann: Theologie der Hoffnung, p. 77.

26 Ibidem, p. 262.

27 Ibidem, p. 303.

28 J. Moltmann: Perspektiven der Theologie, p. 29.

29 Ibidem, p. 28.

30 Ibidem, p. 85

31 Ibidem, p. 30.

32 Ibidem, p. 32

33 J. Moltmann: Theologie der Hoffnung, p. 266.

34 J. Moltmann: Perspektiven der Theologie, p. 206.

35 Ibidem, p. 187.

36 Ibidem, p. 196.

37 Idem.

38 Vide: Ibidem, p 195-6.

39 Ibidem, p. 171.

40 Ibidem, p. 28.

41 Ibidem, p. 209.

42 Ibidem, p. 211.

43 J. Moltmann: Theologie der Hoffnung, p. 74.

44 J. Moltmann: Perspektiven der Theologie, p. 22: „Op slgself beskou Is dit [die ontologiese bewys van God uit ,God'] onaantasbaar maar ook nie by magte om iets aan te tas nie."

45 J. Moltmann: Perspektiven der Theologie, p. 195

46 J. Moltmann: „Die Apokalyptik im Messianismus” in B. Schmidt, op cit., p. 490.

47 Ibidem, p. 491. 